\title{
$\underline{\operatorname{articles}}$
}

\section{Well-being and Social Sustainability, Cross-Cultural Validation of an Emotional Metacognition Traits Scale in Brazilian Adolescents}

\author{
Maria Vaquero-Diego ${ }^{\top}{ }^{\mathrm{a}}$, Maria Botey ${ }^{2} \odot^{\mathrm{b}}$, Samuel Molina Schnorr ${ }^{3} \odot^{\mathrm{c}}$, Ernani Vassoler Rodrigues ${ }^{4} \oplus^{\mathrm{d}}$ \\ 1 Department: Business Administration and Management, ESIC University / ESIC Business \& Marketing School, 2 Department: Computer Science and \\ New Technologies, ESIC University / ESIC Business \& Marketing School, ${ }^{3}$ Center of Science Education, Institute of Biological Sciences, University of \\ Brasília, Brasil, ${ }^{4}$ Department of Physics, Federal University of Espírito Santo, Brazil \\ Keywords: socio-emotional competence, likert scale, emotional intelligence, educational innovation \\ https://doi.org/10.53703/001c.32305
}

\section{Journal of Small Business Strategy}

Vol. 32, Issue 1, 2022

\begin{abstract}
In this work we aimed to examine the reliability and validity of a trait scale on emotional meta-cognition in a large number of subjects (> 11, 000 adolescent students) from a private school network in Brazil. Following up previous validation of the same scale in Europe, we proceed a cross-cultural work in order to analyze its feasibility in assessing the interpersonal emotional intelligence. The study was proceeded during the 2017 academic year, in São Paulo, Brazil. The process included translations and peer content validation of all items from original scale, pilot study in a small sample and the broad survey hereby reported. We, then, proceeded a internal consistency measurement and a factorial analysis, both exploratory and confirmatory. Once the analyses have been carried out we compared emergent dimensions raised from the present research to the original ones, validating the instrument in its majority for the measurement of emotional intelligence in a new cultural set, as well as elucidating subtle differences seen in few items. Considering the sample size, subject cultural diversity and items loads in each factor, we conclude the scale used is an useful tool for mapping the perceived emotional intelligence in Brazilian adolescents, which encourages self-knowledge and informs of the needs in emotional competencies and self-development.
\end{abstract}

\section{Introduction}

Emotional intelligence (EI) is a complex construct that has been defined and instrumentalized to measure in various ways in recent decades (Bar-On, 2006; Brackett et al., 2012; Fernández-Berrocal \& Extremera, 2006; Mikolajczak et al., 2015). Over the time, it shifted from being a questionable concept to become an element of special interest to understand individual differences, to develop interaction and communication skills with others, to access job opportunities, to improve school performance, among others.

Notwithstanding some polisemy on the concept, it is fairly agreed that EI is a multidimensional construct referred to the ability to understand, manage the emotions of one's own and those of others, as well as the possibility of regulating and modifying them (Bar-On, 2006; Salovey et al., 1995). The growing interest in emotional intelligence connects with rapid social and organizational moves, which follows the evolution of individuals' interests (Dulewicz \& Higgs, 1998).
As a result, we find a rapid change of work processes deeply influenced by the adoption of new technologies which, by its turn, change demands of the market, characterizing this new time of globalization and knowledge (Pôrto et al., 2020). The beginnings of the theoretical formulation for the concept of EI were proposed by Salovey \& Mayer (1990), who defined EI as "the ability to direct one's own feelings emotions and that of others; know how to discriminate between them, and use this information to guide thought and self-action" (pp. 189). Later on, Salovey et al. (1995) provided a theoretical framework form EI as well as an empirical instrument for self-reporting the so-called called "Scale trait of metacognition of emotional states" (Trait Meta-Mood Scale, TMMS-48) which yields three dimensions on on EI (clarity, attention and emotional repair) and allows evaluations on perceived emotional intelligence (PEI).

Subsequently, a Spanish version of the empirical instrument, the TMMS-24 was adapted by Fernández-Berrocal et al. (2004), who halved the number of items in the instru-

\footnotetext{
a Camino Valdenigrales s/n. 28223 Pozuelo de Alarcón, Madrid, Spain, maria.vaquero@esic.university

b Camino Valdenigrales s/n. 28223 Pozuelo de Alarcón, Madrid, Spain, maria.botey@esic.university

c Campus Darcy Ribeiro, Institute of Biological Sciences, North Wing, Brasília, DF, Brazil 70910-900, samuel.schnorr@unb.br

d Av. Fernando Ferrari, 514 - Goiabeiras, Vitória - ES, 29075-910, ernani.rodrigues@ufes.br
} 
ment, although retaining its conceptual structure and dimensions of the original. Thus, the instrument has been used in different research contexts, both in the field of social psychology (Aguilar-Luzón et al., 2012; Garrido et al., 2011) and health sciences (Aradilla-Herrero et al., 2014; Lara et al., 2014; Lizeretti et al., 2012) among others. In recent work, Vaquero-Diego et al. (2020) used the TMMS-24 instrument, translating it to Portuguese and applying that to a large scale survey in Brazil, which rose questions on the cross-cultural validity of the instrument and prompted the analysis we will be reporting in this paper. Also, EI studies have been affecting the mainstream thinking on areas of personal development (Rey Peña et al., 2011). On the one hand, it has been found that high levels of EI are positively related to optimism (Extremera et al., 2007), health (Extremera \& Fernández-Berrocal, 2006), self-esteem (Schutte et al., 2002) and adaptation (Boyatzis \& Saatcioglu, 2008). On the other hand, low levels of EI are related to alcohol and drug use, and a high rate of conflicting behaviors (Mayer et al., 2008) and the burnout syndrome (Blanch Plana et al., 2002).

From the educational research sphere, emotional intelligence is gaining particular interest as it envisions benefits in bringing it not only to students but to all the members of school community (Botey et al., 2020). Within the training of students, EI has been shown positively correlated to academic performance, once it influences stress management, intrapersonal skills development and adaptability (Parker et al., 2004). Also, it helps to adjust and clarify thoughts (both negative and positive), promoting an emotional regulation and subsequently, influencing academic performance (Extremera \& Fernández-Berrocal, 2001). Furthermore, Aguayo-Muela \& Aguilar-Luzón (2017) showed that an "emotional educator", i.e. a teacher who has balanced his own emotions, can help students to learn and to develop emotional and affective skills, which is related to the intelligent use of their emotions.

In this regard, instruction on emotional skills could promote personal and intrapersonal skills for students, complementing, thus, their academic training with qualities beyond traditional contents, that contribute to shaping their leadership and, ultimately, could give greater opportunities for succeeding in their later professional careers in a world with an increasingly competitive labor market (Hourani et al., 2020). Some authors, in particular, argue that research supports the conception that EI is a predictor variable for a person's performance in the workplace (Boyatzis \& Saatcioglu, 2008), which in turn can be useful in selection processes (Izquierdo et al., 2007). Their assumption is that people with a high level of EI are more adaptable to stressful life events, using more appropriate coping strategies, coupling the capacity for teamwork and, therefore, would be more likely to successful in the professional field (Bar-On, 1997; Gonzalez et al., 2017; Nikalaou \& Tsaousis, 2002; Prati et al., 2003).

Thus, this work aims to cross-culturally empirically validate a psychometric instrument, largely used in Europe, in a large sample of adolescents in Brazil, comparing latent dimensions an items relational structure, in order to amplify its uses for newer cultural sets.

\section{Theoretical framework}

Brazilian education within the Latin American context requires research that accompanies the evolution of civilizations in new contexts, and also in this moment of global change. To be able to inform about the mental health and well-being of adolescents, it is necessary to seek information on the functioning of the Brazilian educational system, in this specific case the Sesi Schools Network, in the city of São Paulo, where the research has been carried out, the purpose was to validate a scale of self-perceived Emotional Intelligence in adolescents.

In this sense, this research provides information that can help solve situations that unbalance the well-being of students in this case through education (Formichella \& London, 2013; Stallivieri, 2007). With the vision in the education in emotional competences, and for this it is necessary to know the self-perception of Emotional Intelligence that self-inform the students.

Since the 1st World Conference on Health Promotion, held in 1986 in the city of Ottawa (World Health Organization, 1986) educational processes begin to make a place within the field of health, giving it that priority approach to promote personal and social well-being.

WHO reports that mental health is an integral and essential component of health considered as "a state of wellbeing in which the individual realizes his or her own attitudes can cope with the normal pressures of his or her life, can work productively and fruitfully, and is able to make a contribution to his or her community.”, in order to obtain detailed information, we used the applied scale that collects information to recognize the emotional competencies of adolescents.

Based on this idea, the Education 2030 Agenda and its Sustainable Development Goal No. 4 in Education, maintains as a principle the focus on the quality of education in an integral sense, taking into account the emotional competences and well-being of adolescents. Latin American students participate in this international evaluation whose objective is to evaluate in Latin America and the Caribbean the quality of education in basic education (Unesco, 2013).

Authors such as Extremera and Fernández Berrocal (2015) affirm that the main benefits of EI's work in educational contexts are: improved academic performance, increased well-being and psychological adjustment, increased interpersonal relationships, reduced aggressive behaviors, prevention of substance use and/or other addictive behaviors. Other authors highlight that these emotional benefits are accompanied by cognitive benefits (Durlak et al., 2011).

In this scenario, the Brazilian government, as an educational proposal, chooses to use training units on EI that can be aligned with the objective of maintaining the mental health of the members of the educational community. In this way, it seeks to sustain well-being using some principles of emotional intelligence (Federacion de industrias de Sao Paulo, 2021).

\section{Method}

\subsection{The TMMS-24 instrument}

The empirical instrument we are exploring in the present 
analysis has been widely used to evaluate EI in the realm of human resources. As corroborated by a meta-analysis work, carried out by Martins et al. (2010) and confirmed by Fernández-Berrocal et al. (2012), self-report tests in EI have been used during the last years, and $67 \%$ of them corresponded to the TMMS instrument. It have also been used both in organizational (Argoti et al., 2015; Rincón \& Rodríguez, 2018) and educational contexts (Colorado et al., 2012; Contreras et al., 2010).

Besides standard demographic info, the TMMS-24 instrument is set of likert type statements (Likert, 1931) consisting of 24 items, divided into 3 key dimensions (8 items each) of emotional intelligence: 1 . perception; 2 . understanding; and 3. regulation, referred to original ones (clarity, attention and repair). As decribed by Extremera \& Fernández-Berrocal (2005), emotional perception (1stdim) is the ability to identify and recognize both one's own feelings and those of others, while emotional understanding (2nd dim.) implies the ability to deploy a repertoire of emotional signals, label emotions and recognize in which categories feelings are grouped and lastly, emotional regulation (3rd dim.) includes the ability to be open to feelings, both positive and negative, and reflect on them to take advantage of them in a positive way.

\subsection{Research context}

The study was established on a private school network in the state of São Paulo, Brazil, encompassing students from secondary school (SESI-SP) in the 7th and 9th years of elementary education, and the 3rd year of secondary education, adolescents between 14 and 19. The criterion used for including these courses followed two facts: first, those school years correspond to intense adolescence stages, as described by Aberastury (1983) and Blos (1986); then, by that time (October-December 2017) those classes were taking the São Paulo State Performance Assessment test, which gathered a large number of students at the same time in similar scenario at their school unities.

The TMMS-24 questionnaire was given to $14,000 \mathrm{stu}-$ dents, from which we obtain 11,370 responses with 11,283 complete cases (5,699 girls and 5,584 boys), therefore, it is an exhaustive sample of adolescent students from São Paulo. According to the ethical criteria provided by Brazilian law, the study was framed in human research with minimal risks in such a way that all participants were included prior diligence of informed consent, guaranteeing in all cases, the right to confidentiality and anonymity. This study also complies with the ethical considerations of the Helsinki Declaration and the ethics criteria and had previous authorization both from the school network principal and from the parents of the test subjects.

\subsection{Procedure}

Prior to carry out the survey with the subjects, the Spanish version of the TMMS-24 questionnaire was translated and had its content validity reviewed by members of a research group composed by specialists in educational field, who verified item's translation, its suitability for the research, retaining the original ideas.

The TMMS-24 instrument was then applied to a pilot group, within the same research group, highlighting the precise definition of the domain and the judgment on the degree of sufficiency with which the domain is evaluated, both relevant aspects of the questionnaire (Barajas \& Edith, 2011).

Next, after receiving authorization from the school network, which included a meeting with the principal, a, IT professional received from the researcher an online form, which was spread to the IT teachers in the network. The IT teachers were informed of the objectives of the study as well as instructions for students to answer the TMMS-24 questionnaire. The forms were applied at the computer classrooms, where each student could have his own PC for answer. At all times from the coordination of research, contact was made by phone to IT teachers who apply the questionnaires in the classroom. The instructions detail that filling out the questionnaire involved tacit consent for participation in the study. The time required to complete the questionnaires took between 15 and 25 minutes. Subjects collaboration was voluntary, anonymous and selfless.

\subsection{Data analysis}

The instrument figures a quantitative instrumental approach and is geared towards addressing the psychometric properties of tests, according to its original constructs. Then, the "likert" data collected was analyzed through (a) descriptive statistics, (b) measurement of internal consistence (Cronbach, 1970; McDonald, 1999) and (c) both exploratory and confirmatory factor analysis (Fernández, 1998; Martínez Arias, 1995). The data analyses were carried out R Software (Ihaka et al., 1993) software, with the packages cocron (Diedenhofen, 2016), corrplot (Wei \& Simko, 2017), HH (Heiberger \& Holland, 2020), lavaan (Rosseel, 2012), nFactors (Raiche \& Magis, 2020), psych (Revelle, 2020) and semPlot (Epskamp, 2019).

Empirical studies in psychology commonly report that Cronbach's alpha is a measure of the reliability of internal consistency. However, concerns on Cronbach alpha regarding the problem stemmed from unrealistic assumptions can be seen in methodological studies (Dunn et al., 2014; Geldhof et al., 2014; Peters et al., 2015). Although there are numerous indicators alternative to Cronbach's alpha, in this study we used also the McDonald's omega coefficient (McDonald, 1999; Raykov, 2001; Raykov \& Shrout, 2002) considering its suitability for discrete variables. Another relevant discussion is the cut-off points definition for internal consistency indexes. In the case of McDonald's omega, it can be acceptable in ranges varying from .7 and .9 (CampoArias \& Oviedo, 2008), even though in some circumstances values greater than .65 may be accepted (Katz, 2006). In the case of the Cronbach's alpha, the minimum acceptable value can be above .6 (Taber, 2018). Avoiding disputes over arbitrary cutting points, both $\alpha$ and $\omega$ are reported.

As this study is quantitative in nature, we proceed both descriptive and inferential analysis for comparing emergent dimensions from the TMMS-24 instrument in Brazil to the dimensions reported in the original TMSS-24 Spanish study, in order to validate its usage in the South American context. Fernández (1998) stresses that it is understood that an instrument is reliable if it has consistency with respect 

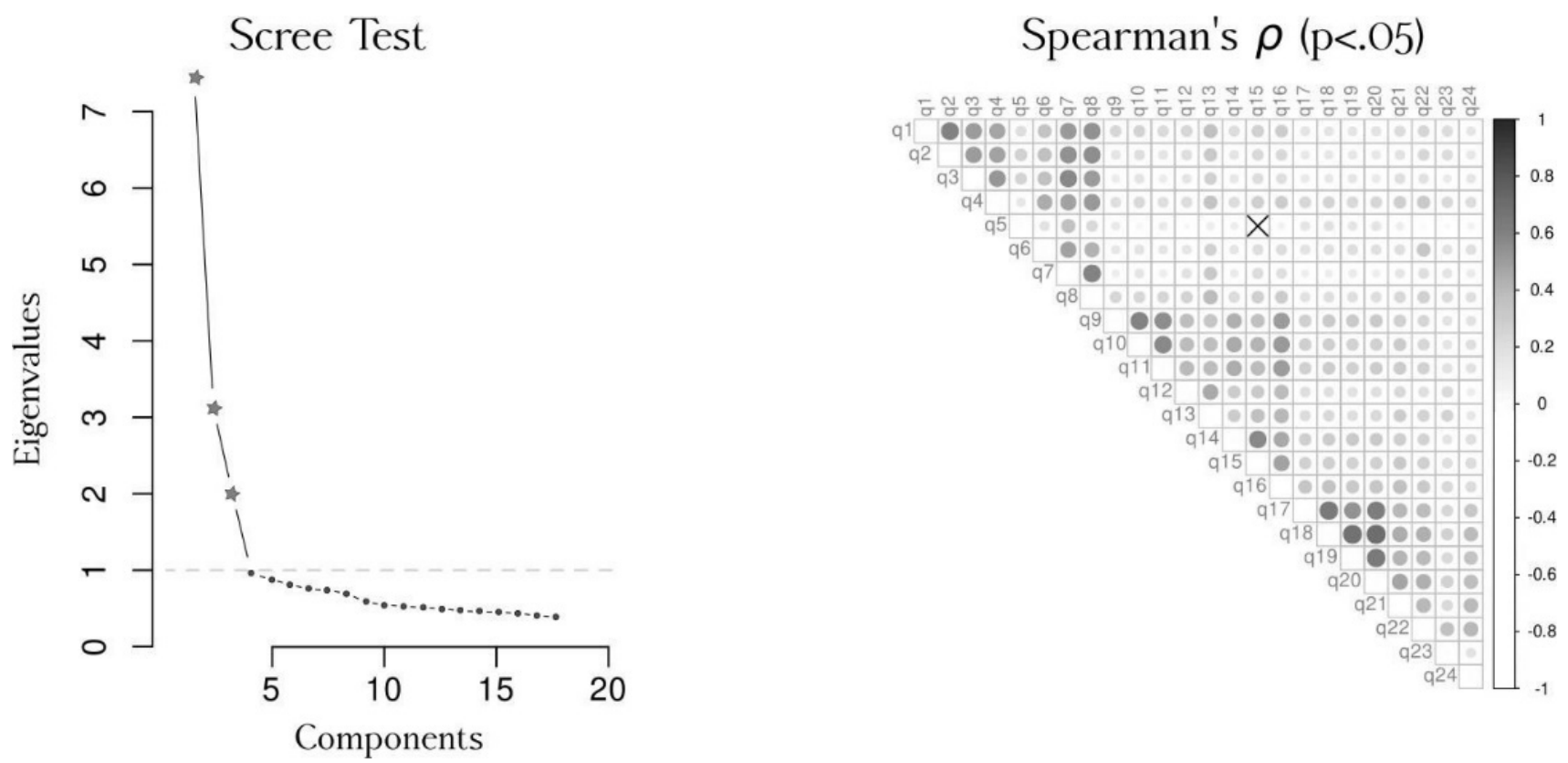

Fig. 1. Scree test (left) for determining the number of factors to retain and Spearman's $\rho$ matrix for describing correlation between items response distribution

to its application in various environments (different places and/or time). On the other side of the coin, validity can be considered as an attribute indicating the degree to which the instrument measures the constructs for which it has been created. Thus, the numerical indicators computed were used for inferring both reliability and validity of the test in a cross-cultural context.

\section{Results}

The overall internal consistency indexes computed were $\alpha_{\text {cronb }}=.90$ and $\omega_{\text {mcdon }}=.92$.

The Scree test informed that 3 components are enough for explaining most of data variance (Fig. 1, left), showing three factors with eigenvalues greater than $1(\lambda 1=6.656$, $\lambda 2=3.482$ and $\lambda 3=2.260$ ), which accounted for $46 \%$ of total data variance. The Spearman's correlation matrix for $\mathrm{p}<$ .05 reject only q5/q15 correlation (Fig. 1, right).

The exploratory factor analysis and items respective loads (> .35) in each factor are shown in Table 1, detailing per factor both internal consistency index used and the amount of explained variance.

The structural analysis showed a model $a$ priori containing all items of the TMMS-24 instrument (Fig. 2, upper). A multidimensional projection was detected for the item 13 , and the items 5, 23 and 24 showed loads near to the .35 off point, as a consequence, a model with out-of-range goodness-of-fit indices is obtained. Thus, a structural model $a$ posteriori was proceeded, excluding those ones and retaining the remaining 20 items (Fig. 2 lower).

The posteriori model kept its acceptable internal consistency, maintaining Cronbach's alpha $\left(\alpha_{\text {cronb }}=.90\right)$ and increasing McDonald's omega $\left(\omega_{\text {mcdon }}=.93\right)$. In both models, correlation between emotional clarity and emotional repair are the largest and the pair emotional attention and emo- tional repair are the smallest.

After the elimination of the 4 items, good results were obtained in terms of the fit indices, affirming the goodness of fit of the TMMS-20 model (AGFI= 0.92; GFI = 0.94; CFI= 0.95; RMSR $=0.06 ; \mathrm{RMR}=0.08 ; \mathrm{NFI}=0.93$ ).

The responses distribution is shown in Fig. 3, explicit the overall tendencies in each item. It can be observed that item 23 is the highest item by far in relation to the others, which could be an element of distortion, as most of them give the same response; strongly agree. Item 5 also stands out as the lowest frequency of intermediate values in the attention dimension.

\section{Discussion}

The dimensions that emerged in the Brazilian adolescent population maintained the same structure as the original research instrument Salovey et al. (1995). That points to the validity of the constructions, even when they are investigated in a different cultural context. This feature reinforces the potential of EI and IPE as a non-idiosyncratic human characteristic. In addition, the high values of the instrument's internal consistency indices for each subscales support the instrument's reliability assumption. Likewise, the CFA contributes to validate the constructs, demonstrating that the items tend to cluster in the dimensions of attention, clarity and repair, proposed by the authors of the scale, where items 23 and 24 presented the lowest factorial weight in the repair dimension, 5 and 13 in the attention and clarity dimensions respectively.

Taking into account the elements removed from the original, its divergence from the TMMS-24 may stem from the translation process or from social or cultural differences with respect to self-declaration. The 4 items removed from the instrument were $5,13,23$ and 24 , in general because they did not reach valid values both in the analytical part 
Table 1. TMMS-24 Explained variances, internal consistency and item loads (> .35), per factor

\begin{tabular}{|c|c|c|c|c|c|c|c|}
\hline Dim. & Item & F. 1 & F. 2 & F. 3 & Expl. Var. & acronb & wmcdon \\
\hline \multirow{8}{*}{ Attention } & $\mathrm{q} 1$ & .67 & & & \multirow{8}{*}{$16 \%$} & \multirow{8}{*}{.85} & \multirow{8}{*}{.88} \\
\hline & q2 & .71 & & & & & \\
\hline & q3 & .69 & & & & & \\
\hline & $\mathrm{q} 4$ & .62 & & & & & \\
\hline & q5 & .44 & & & & & \\
\hline & q6 & .52 & & & & & \\
\hline & q7 & .79 & & & & & \\
\hline & q8 & .70 & & & & & \\
\hline \multirow{8}{*}{ Clarity } & q9 & & .68 & & \multirow{8}{*}{$15 \%$} & \multirow{8}{*}{.86} & \multirow{8}{*}{.89} \\
\hline & q10 & & .72 & & & & \\
\hline & q11 & & .71 & & & & \\
\hline & $\mathrm{q} 12$ & & .51 & & & & \\
\hline & q13 & .36 & .48 & & & & \\
\hline & q14 & & .60 & & & & \\
\hline & q15 & & .54 & & & & \\
\hline & $\mathrm{q} 16$ & & .65 & & & & \\
\hline \multirow{8}{*}{ Repair } & q17 & & & .69 & \multirow{8}{*}{$15 \%$} & \multirow{8}{*}{.86} & \multirow{8}{*}{.88} \\
\hline & q18 & & & .82 & & & \\
\hline & q19 & & & .72 & & & \\
\hline & q20 & & & .80 & & & \\
\hline & q21 & & & .52 & & & \\
\hline & q22 & & & .53 & & & \\
\hline & q23 & & & .32 & & & \\
\hline & q24 & & & .48 & & & \\
\hline
\end{tabular}

(model with poor goodness-of-fit indices) and in the conceptual part, since in the regional context they do not show consistency with the definition of the corresponding construct.

In particular, item 5 corresponds to the dimension of attention, which confronts the subjects with the possibility of feeling and allows feelings to flow, this can cause this item to lead to a misunderstanding about a lack of control over feelings. Item 13 corresponds to the dimension of clarity and questions the number of times the interviewee recognizes and understands their emotional states, as it is a quantitative response and does not specify the specific amount in each option on the Likert scale, it can lead to an error in the answer. Item 23 corresponds to the repair dimension and aims to determine the level of performance and management thrills, it may not fit the TMMS model by associating the action of having energy with a feeling of happiness. Item 24 also corresponds to the dimension of repair in the initial scale and its non-inclusion in the Brazilian model may be due to the use and meaning of the verb try (try, in Spanish), since it implies doubts and is difficult to quantify.

There are numerous applications of the TMMS instrument for different contexts in which some items did not reach valid values and were excluded from the instrument, as in the case of Argentina (Calero, 2013), where the re- searcher submitted the instrument to its validation obtaining a scale of 21 items. In another study, Rincón \& Rodríguez (2018) examined the reliability and validity of the TMMS in a group of teachers from private institutions of higher education in Bolivia, also obtaining a reduced scale of 20 Items in their validation. Other studies (Martín-Albo et al., 2010; Salguero et al., 2010) eliminate item 23 from the scale and item 5 , because they have low levels of contribution to their dimension. However, Aradilla-Herrero (2014) advises keeping item 23 despite its low contribution.

Once the research is carried out in an educational context, the dimensions detected can offer a path to the curricular trainers in order to include the development of these competences, as suggested by Extremera \& FernándezBerrocal (2006), promoting a broader development for students and preparing them to deal with their own emotional states in a dynamic and often oppressive world.

\section{Conclusions}

Each culture has its own rules of emotional expression that are acquired through learning and modulate the meaning of emotions. In this way, culture crosses and influences the way in which emotions are interpreted, intensifying, decreasing, substituting or neutralizing their appearance and/ or expression (Ekman et al., 1969). 


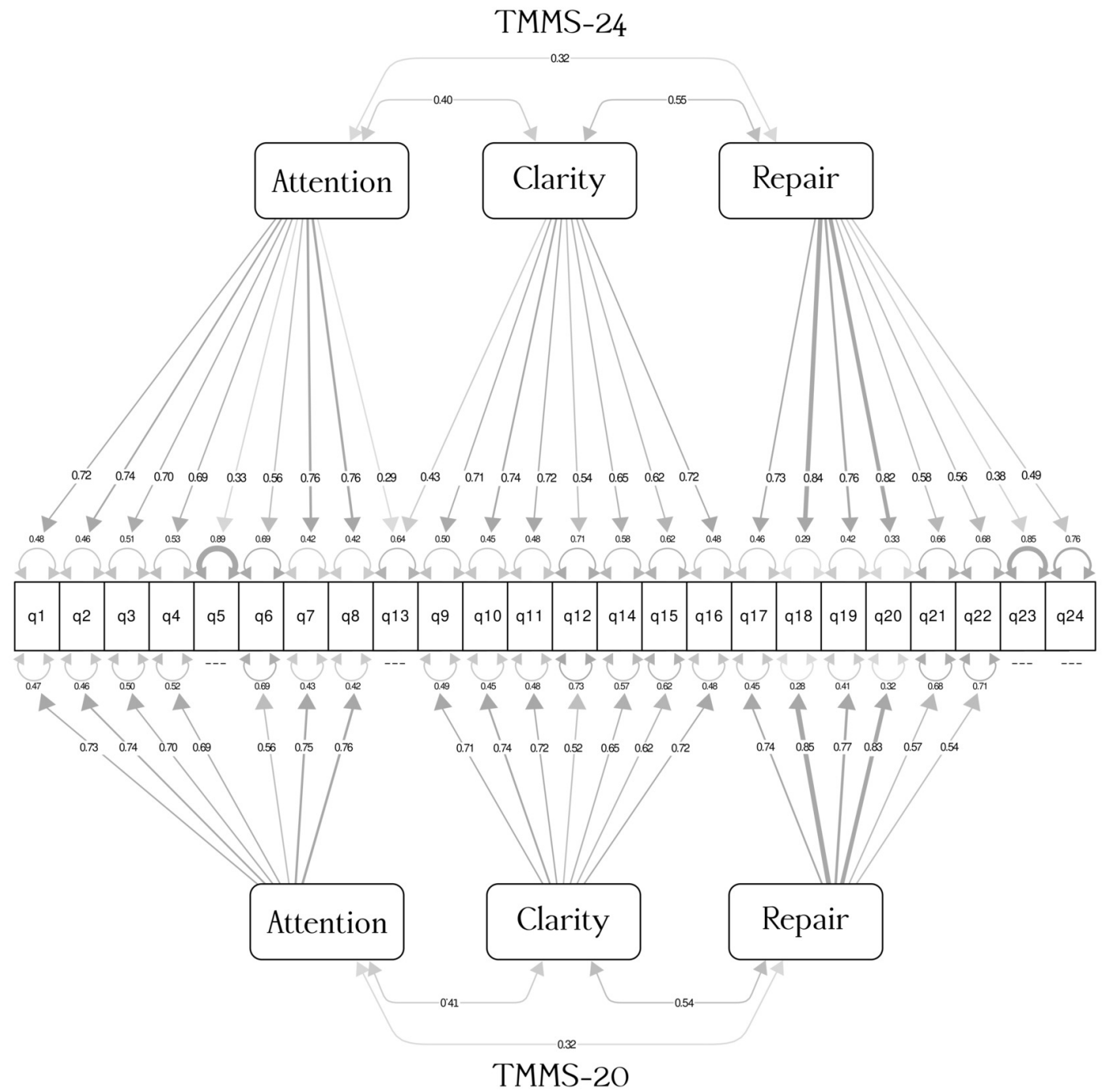

Fig. 2. Structural equation modeling from both the TMMS-24 (above) and our TMMS-20 (below)

Among the various instruments that exist to measure EI, the Trait Meta-Mood Scale-TMMS- stands out as one of the most widely used tools worldwide. It allows to obtain an index that values the knowledge that each person possesses about their own emotional states, providing a personal estimate on the reflective aspects of the emotional experience.

This study aimed to validate the instrument TMMS-24 (Salovey et al., 1995) in the Brazilian environment, for this purpose it was translated into Portuguese and the texts were adapted to the cultural characteristics of the environment in which it was applied. The internal consistency was adequate and the dimensions that emerged in the Brazilian population studied maintained the same structure as the original research instrument, with the exception that four items were eliminated for reasons stated above. Therefore, with this study is obtained in TMMS-20-BR, which allows the study of the Emotional Intelligence of individuals in the Brazilian population. Having this instrument properly adapted to Brazil allows valid comparisons with the results obtained in other countries.

Among the limitations of the study, it should be noted that the sample used is made up of adolescents from São Paulo and not from the whole of Brazil; perhaps the study could be extended to adolescent populations in other regions.

Learning to face frustration, to control anger, to motivate oneself and to foster empathy are emotional competences whose mastery allows us to be better prepared for life (Pérez Escoda \& Filella Guiu, 2019). therefore, educational organizations and school staff must take into account the emotional profiles of students by designing interventions adapted to the recipients with an active and motivating methodology. Therefore, it is essential to have instruments that allow to measure the different aspects of Emotional Intelligence, which facilitates an adequate design of learning and professional trajectories with the aim of obtaining desirable social results such as greater happiness of the person or better performance in the company (Ingram et al., 2019).

Therefore, a very interesting line of research that could be a continuation of this study is to characterize the sample according to sociodemographic variables (age and sex) identifying the possible strengths and deficiencies of each group in EI and designing appropriate learning trajectories that improve their EI.

In recent years, technology has been slowly entering the classroom, but the COVID-19 pandemic has accelerated the 


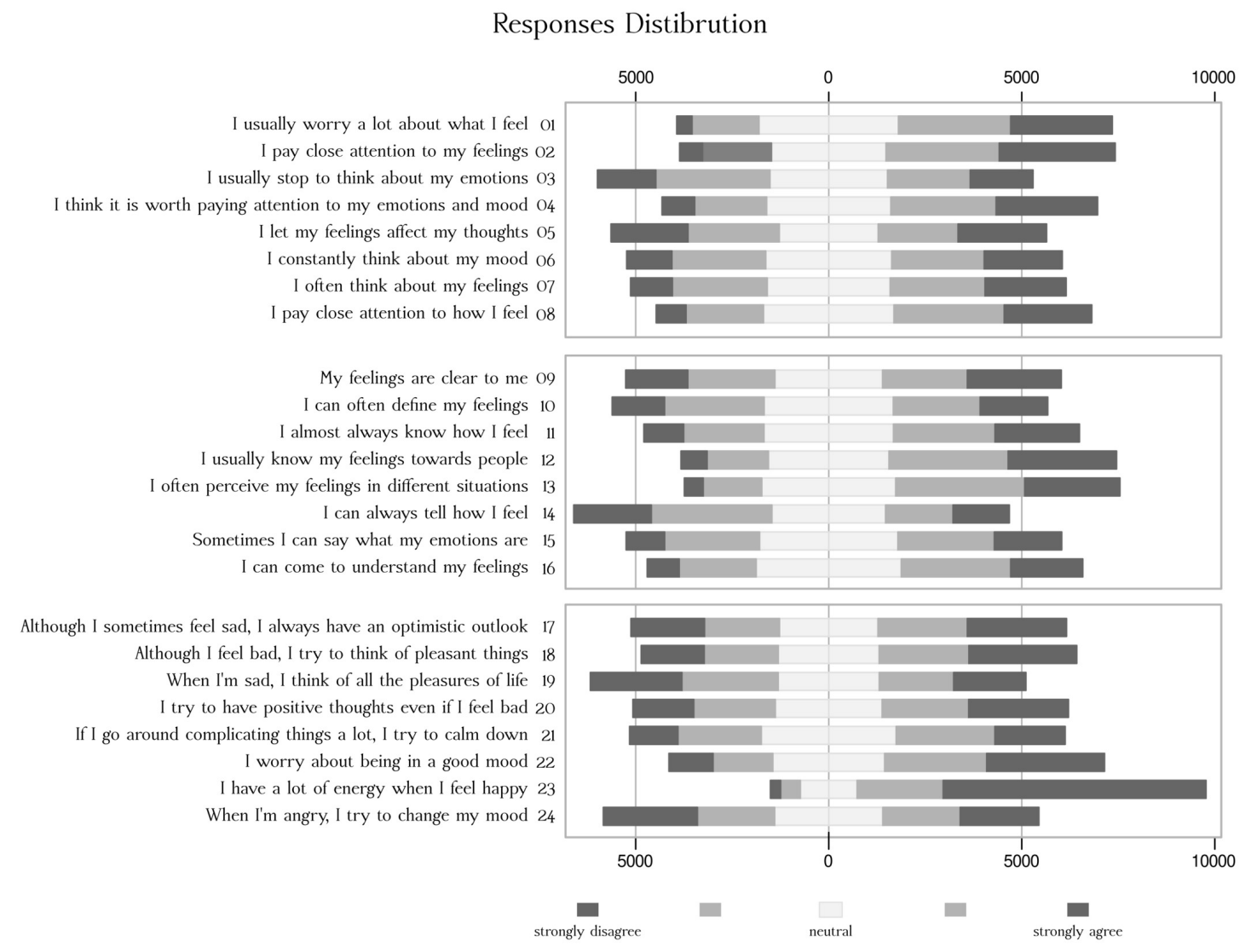

\section{Fig. 3. TMMS-24 items and responses distribution}

process in an unimaginable way. Thus, in order for educational institutions to know the emotional state and/or capacity of their students, it is necessary to access it possibly through devices that all students possess, with which it is possible to offer to carry out a self-assessment of emotional intelligence on-line. However, in this situation, all interpretation depends on written text and also provides the possibility of more time, allowing the answers to be not so spontaneous. This seems to be one of the future avenues of research, as this change of modality may require an adaptation of the model.

Submitted: July 19, 2021 CST, Accepted: January 21, 2022 CST

This is an open-access article distributed under the terms of the Creative Commons Attribution 4.0 International License (CCBY-4.0). View this license's legal deed at http://creativecommons.org/licenses/by/4.0 and legal code at http://creativecommons.org/licenses/by/4.0/legalcode for more information. 


\section{REFERENCES}

Aberastury, A. (1983). Adolescência. Artmed.

Aguayo-Muela, Á. del C., \& Aguilar-Luzón, M. (2017). Principales resultados de investigación sobre inteligencia emocional en docentes españoles. Revista Electrónica de Investigación Docencia Creativa, 6, 170-193. https://doi.org/10.30827/digibug.45497

Aguilar-Luzón, M. C., Calvo-Salguero, A., \& Monteoliva-Sánchez, A. (2012). La inteligencia emocional percibida y su relación con el apego adulto. Psychology/ Psicologia Conductual, 20, 119-135.

Aradilla-Herrero, A., Tomás-Sábado, J., \& GómezBenito, J. (2014). Perceived emotional intelligence in nursing: Psychometric properties of the Trait MetaMood Scale. Journal of Clinical Nursing, 23(7-8), 955-966. https://doi.org/10.1111/jocn.12259

Argoti, E. E., Romero, M. J. A., \& Porras, L. M. G. (2015). Relación de la inteligencia emocional con el desempeño laboral. Ciencia \& Salud.

Barajas, L., \& Edith, Y. (2011). Una reseña sobre la validez de constructo de pruebas referidas a criterio. Perfiles Educativos, 33, 131-154.

Bar-On, R. (1997). The bar-on model of emotional-social intelligence (esi).

Bar-On, R. (2006). The bar-on model of emotional-social intelligence (esi). Psicothema, 18, 13-25. http://www.r edalyc.org/resumen.oa?id=72709503

Blanch Plana, A., Aluja Fabregat, A., \& Biscarri Gassió, J. (2002). Síndrome de quemarse en el trabajo (burnout) y estrategias de afrontamiento: Un modelo de relaciones estructurales. Revista de Psicología del Trabajo y de las Organizaciones, 18(1), 57-74.

Blos, P. (1986). L'adolescenza Un'interpretazione psicoanalitica. Codice.

Botey, M., Vaquero-Diego, M., \& Sastre, F. J. (2020). Perceived emotional intelligence of university professors based on the nature of the subject taught. Technological Forecasting and Social Change, 161. http s://doi.org/10.1016/j.techfore.2020.120292

Boyatzis, R. E., \& Saatcioglu, A. (2008). A 20-year view of trying to develop emotional, social and cognitive intelligence competencies in graduate management education. Journal of Management Development, 27(1), 92-108. https://doi.org/10.1108/02621710810840785

Brackett, M. A., Rivers, S. E., Reyes, M. R., \& Salovey, P. (2012). Enhancing academic performance and social and emotional competence with the ruler feeling words curriculum. Learning and Individual Differences, 22(2), 218-224. https://doi.org/10.1016/j.lindif.2010.1 $\underline{0.002}$

Calero, A. (2013). Argentinean version of TMMS for adolescents: A perceived emotional intelligence measure. Panamerican Journal of Neuropshychology, 104-119. https://doi.org/10.7714/cnps/7.1.206

Campo-Arias, A., \& Oviedo, H. C. (2008). Propiedades psicométricas de una escala: La consistencia interna. Revista de Salud Pública, 10(5), 831-839. https://doi.o $\mathrm{rg} / 10.1590 / \mathrm{s} 0124-00642008000500015$
Colorado, Y. S., García, K. G., Alfonso, L. M., \& Ospino, G. C. (2012). Characteristics of emotional intelligence in psychology students and business administration of a public university of Santa Marta, Colombia: A pilot study. Revista Duazary, 9, 132-139.

Contreras, F., Barbosa, D., \& Espinosa, J. C. (2010). Personalidad, inteligencia emocional y afectividad en estudiantes universitarios de áreas empresariales implicaciones para la formación de líderes. Diversitas, 6(1), 65-79. https://doi.org/10.15332/s1794-9998.201 0.0001 .05

Cronbach, L. J. (1970). Essentials of psychological testing (3rd ed.). Harper \& Row.

Diedenhofen, B. (2016). Cocron: Statistical Comparisons of Two or more Alpha Coefficients (Version 1.0-1). htt p://comparingcronbachalphas.org

Dulewicz, V., \& Higgs, M. (1998). Emotional intelligence: Managerial fad or valid construct? (Working Paper Series).

Dunn, T. J., Baguley, T., \& Brunsden, V. (2014). From alpha to omega: A practical solution to the pervasive problem of internal consistency estimation. British Journal of Psychology, 105(3), 399-412. https://doi.or $\mathrm{g} / 10.1111 /$ bjop.12046

Durlak, J. A., Weissberg, R. P., Dymnicki, A. B., Taylor, R. D., \& Schellinger, K. B. (2011). The impact of enhancing students' social and emotional learning: A meta-analysis of school-based universal interventions. Child Development, 82(1), 405-432. htt ps://doi.org/10.1111/j.1467-8624.2010.01564.X

Ekman, P., Sorenson, E. R., \& Friesen, W. V. (1969). Pancultural elements in facial displays of emotion. Science, 164(3875), 86-88. https://doi.org/10.1126/sci ence.164.3875.86

Epskamp, S. (2019). semPlot: Path Diagrams and Visual Analysis of Various SEM PackagesOutput (r package version 1.1.2). https://CRAN.R-project.org/package $=$ se $\underline{\text { mPlot }}$

Extremera, N. P., Durán, M., \& Rey, L. (2007). Inteligencia emocional y su relación con los niveles de burnout, engagement y estrés en estudiantes universitarios. Revista de Educación, 342, 239-256.

Extremera, N. P., \& Fernández Berrocal, P. (2015). Inteligencia emocional y educación. Editorial Grupo 5.

Extremera, N. P., \& Fernández-Berrocal, P. (2001). ¿Es la inteligencia emocional un adecuado predictor del rendimiento académico en estudiantes? (pp. 146-157).

Extremera, N. P., \& Fernández-Berrocal, P. (2005). Perceived emotional intelligence and life satisfaction: Predictive and incremental validity using the trait meta-mood scale. Personality and Individual Differences, 39(5), 937-948. https://doi.org/10.1016/ j.paid.2005.03.012

Extremera, N. P., \& Fernández-Berrocal, P. (2006). Emotional intelligence as predictor of mental, social, and physical health in university students. The Spanish Journal of Psychology, 9(1), 45-51. https://do i.org/10.1017/s1138741600005965 
Federacion de industrias de Sao Paulo. (2021). Inteligência Emocional: Mantendo a saúde mental. http s://coronavirus.fiesp.com.br/blog/inteligencia-emocio nal-mantendo-a-saude-mental

Fernández, J. M. (1998). La medición de lo psicológico. Psicothema, 10, 1-21. https://reunido.uniovi.es/inde x.php/PST/article/download/7442/7306

Fernández-Berrocal, P., Berrios-Martos, M. P., Extremera, N., \& Augusto, J. M. (2012). Inteligencia emocional: 22 años d avances empíricos. Psicología Conductual, 20, 5.

Fernández-Berrocal, P., \& Extremera, N. (2006). Emotional intelligence: A theoretical and empirical review of its first 15 years of history. Psicothema, 18 , 7-12.

Fernández-Berrocal, P., Extremera, N., \& Ramos, N. (2004). Validity and reliability of the spanish modified version of the trait meta-mood scale. Psychological Reports, 94, 751-755. https://doi.org/10.2466/pr0.94.3

Formichella, M. M., \& London, S. (2013). Empleabilidad, educación y equidad social*/Employability, Education, and Social Equality/Empregabilidade, educação e equidade social. Revista de Estudios Sociales.

Garrido, M. P., Pacheco, N. E., \& Peña, L. R. (2011). El papel de la inteligencia emocional en la resolución de problemas sociales en estudiantes adolescentes. REOP - Revista Española de Orientación y Psicopedagogía, 22(1), 69-79. https://doi.org/10.5944/ reop.vol.22.num.1.2011.78

Geldhof, G. J., Preacher, K. J., \& Zyphur, M. J. (2014). Reliability estimation in a multilevel confirmatory factor analysis framework. Psychological Methods, 19(1), 72-91. https://doi.org/10.1037/a0032138

Gonzalez, A. C., Rodriguez, Y., \& Sossa, A. (2017). Leadership and governance decisions in family business performance: An application of fuzzy sets logic. Journal of Small Business Strategy, 27(1), 51-66. https://ibjournals.mtsu.edu/index.php/jsbs/article/vi ew/760

Heiberger, R. M., \& Holland, B. (2020). HH: Statistical Analysis and Data Display (Version 3.1-40). https://CR AN.R-project.org/package $=\mathrm{HH}$

Hourani, R. B., Litz, D., \& Smith, A. (2020). Multidimensional leaders' roles and responsibilities: Dynamics, constraints and policy change in a UAE juvenile correctional educational center. Educational Management Administration \& Leadership, 48(4), 682-702. https://doi.org/10.1177/1741143219833691

Ihaka, R., Gentleman, R., \& team, R. C. (1993). R: A language and environment for statistical computing. htt ps://www.R-project.org/

Ingram, A., Peake, W. O., Stewart, W., \& Watson, W. (2019). Emotional intelligence and venture performance. Journal of Small Business Management, 57(3), 780-800. https://doi.org/10.1111/jsbm.12333

Izquierdo, A. L. G., Izquierdo, M. G., \& Villagrasa, P. J. R. (2007). Aportaciones de la inteligencia emocional y la autoeficacia: Aplicaciones para la selección de personal. Anales de Psicología, 23, 231-239.
Katz, M. H. (2006). Multivariable analysis. Cambridge University Press. https://doi.org/10.1017/cbo9780511 $\underline{811692}$

Lara, F. J. P., Carranque, G., Oehling, H., Hernández, J. M., \& Oliva, H. (2014). Psychological modulation in patients surgically intervened for gastroesophageal reflux disease. Diseases of the Esophagus, 27(6), 538-546. https://doi.org/10.1111/j.1442-2050.2012.0 1443.X

Likert, R. A. (1931). A technique for the measurement of attitudes. Archive of Psychology, 140, 55.

Lizeretti, N. P., Extremera, N., \& Rodríguez, A. (2012). Perceived emotional intelligence and clinical symptoms in mental disorders. Psychiatric Quarterly, 83(4), 407-418. https://doi.org/10.1007/s11126-012-9 $\underline{211-9}$

Martín-Albo, J., Nuñez, J. L., \& León, J. (2010). Analysis of the psychometric properties of the Spanish version of the Trait Meta-Mood Scale in a sports context. Psychological Reports, 106(2), 477-489. https://doi.or $\mathrm{g} / 10.2466 / \mathrm{pr} 0.106 .2 .477-489$

Martínez Arias, R. (1995). Psicometría: Teoría de los tests psicológicos y educativos.

Martins, A., Ramalho, N., \& Morin, E. (2010). A comprehensive meta-analysis of the relationship between emotional intelligence and health. Personality and Individual Differences, 49, 554-564. htt ps://doi.org/10.1016/i.paid

Mayer, J. D., Roberts, R. D., \& Barsade, S. G. (2008). Emerging research in emotional intelligence. Annual Review of Psychology, 59(1), 507-536. https://doi.org/1 0.1146/annurev.psych.59.103006.093646

McDonald, R. P. (1999). Test theory: A unified treatment. Lawrence Erlbaum Associates.

Mikolajczak, M., Avalosse, H., Vancorenland, S., Verniest, R., Callens, M., Van Broeck, N., FantiniHauwel, C., \& Mierop, A. (2015). A nationally representative study of emotional competence and health. Emotion, 15(5), 653-667. https://doi.org/10.10 37/emo0000034

Nikalaou, I., \& Tsaousis, I. (2002). Emotional intelligence in the workplace: Exploring its effects on occupational stress and organizational commitment. International Journal of Organizational Analysis, 10(4), 327-342. https://doi.org/10.1108/eb028956

Parker, J. D. A., Summerfeldt, L. J., Hogan, M. J., \& Majeski, S. A. (2004). Emotional intelligence and academic success: Examining the transition from high school to university. Personality and Individual Differences, 36(1), 163-172. https://doi.org/10.1016/s 0191-8869(03)00076-X

Pérez Escoda, N., \& Filella Guiu, G. (2019). Educación emocional para el desarrollo de competencias emocionales en niños y adolescentes. Praxis \& Saber, 10(24), 23-44. https://doi.org/10.19053/22160159.v1 $\underline{0 . n 25.2019 .8941}$ 
Peters, G.-J. Y., De Bruin, M., \& Crutzen, R. (2015). Everything should be as simple as possible, but no simpler: Towards a protocol for accumulating evidence regarding the active content of health behaviour change interventions. Health Psychology Review, 9(1), 1-14. https://doi.org/10.1080/1743719 9.2013.848409

Pôrto, M. G., Tartarotti, L., \& da Costa Bagattini, L. (2020). Inteligência emocional e o perfil de líderes de uma cidade na serra gaúcha. Saber Humano: Revista Científica da Faculdade Antonio Meneghetti, 10(16). htt ps://doi.org/10.18815/sh.2020v10n16.423

Prati, L. M., Douglas, C., Ferris, G. R., Ammeter, A. P., \& Buckley, M. R. (2003). The role of emotional intelligence in team leadership: Reply to the critique by antonakis. The International Journal of Organizational Analysis, 11(4), 363-369. https://doi.or $\mathrm{g} / 10.1108 / \mathrm{eb028981}$

Raiche, G., \& Magis, D. (2020). nFactors: Parallel Analysis and Other Non Graphical Solutions to the Cattell Scree Test (R package version 2.4.1). https://CR AN.R-project.org/package $=$ nFactors

Raykov, T. (2001). Bias of coefficient afor fixed congeneric measures with correlated errors. Applied Psychological Measurement, 25(1), 69-76. https://doi.o rg/10.1177/01466216010251005

Raykov, T., \& Shrout, P. E. (2002). Reliability of scales with general structure: Point and interval estimation using a structural equation modeling approach. Structural Equation Modeling, 9(2), 195-212. https://d oi.org/10.1207/s15328007sem0902_3

Revelle, W. (2020). psych: Procedures for Psychological, Psychometric, and Personality Research (r package version 2.0.12). Northwestern University Evanston. htt ps://CRAN.R-project.org/package=psych

Rey Peña, L., Extremera, N., \& Pena, M. (2011). Perceived emotional intelligence, self-esteem and life satisfaction in adolescents. Psychosocial Intervention, 20, 227-234. https://doi.org/10.5093/in2011v20n2a10

Rincón, R. A., \& Rodríguez, Á. P. A. (2018). Validity and reliability of the trait emotional meta-cognition scale (tmms-24) in university teachers. Revista Lebret, 10, 61-72. https://doi.org/10.15332/rl.v0i10.2197

Rosseel, Y. (2012). lavaan: An R package for structural equation modeling. Journal of Statistical Software, 48(2), 1-36. https://doi.org/10.18637/jss.v048.i02
Salguero, J. M., Fernández-Berrocal, P., Balluerka, N., \& Aritzeta, A. (2010). Measuring perceived emotional intelligence in the adolescent population: Psychometric properties of the Trait Meta-Mood Scale. Social Behavior and Personality, 38(9), 1197-1210. https://doi.org/10.2224/sbp.2010.38.9.11 97

Salovey, P., \& Mayer, J. D. (1990). Emotional intelligence. Imagination, Cognition and Personality, 9(3), 185-211. https://doi.org/10.2190/dugg-p24e-52 wk-6cdg

Salovey, P., Mayer, J. D., Goldman, S. L., Turvey, C., \& Palfai, T. P. (1995). Emotional attention, clarity, and repair: Exploring emotional intelligence using the trait meta-mood scale. In Emotion, disclosure, \& health (pp. 125-154). American Psychological Association.

Schutte, N. S., Malouff, J. M., Simunek, M., McKenley, J., \& Hollander, S. (2002). Characteristic emotional intelligence and emotional well-being. Cognition and Emotion, 16(6), 769-785. https://doi.org/10.1080/026 99930143000482

Stallivieri, L. (2007). El sistema de educación superior de brasil: Características, tendencias y perspectivas.

Taber, K. S. (2018). The use of cronbach's alpha when developing and reporting research instruments in science education. Research in Science Education, 48(6), 1273-1296. https://doi.org/10.1007/s11165-01 6-9602-2

Unesco. (2013). Situación Educativa De América Latina Y El Caribe: Hacia la eduación de calidad para todos al 2015. Orealc/Unesco.

Vaquero-Diego, M., Torrijos-Fincias, P., \& RodriguezConde, M. J. (2020). Trait meta-mood, gender and eeg response during emotion-regulation. Psicologia: Reflexão e Crítica, 33(1), 1. https://doi.org/10.1186/s41 155-019-0139-y

Wei, T., \& Simko, V. (2017). R package "corrplot": Visualization of a Correlation Matrix (Version 0.84). htt ps://github.com/taiyun/corrplot

World Health Organization. (1986, November 21). Ottawa Charter for Health Promotion. First International Conference on Health Promotion, Ottawa, Ontario, Canada. http://www1.paho.org/span ish/hpp/ottawachartersp.pdf?ua=1 